\title{
AMEGHINIANA Amonomum
}

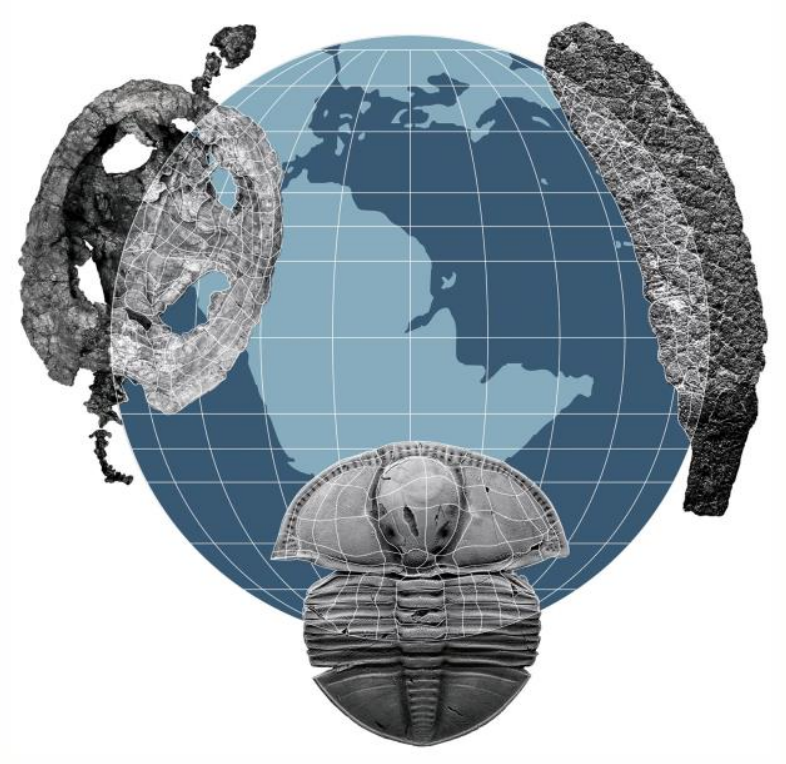

contained in this volume are to be published in future issues of the journal.

Please be aware that during the production process errors may be discovered which could affect the content.

All legal disclaimers that apply to the journal pertain.

Submitted: November 15 $15^{\text {th }}, 2017$ - Accepted: March 19th, 2018 - Published online: March $23^{\text {th }}, 2018$

To link and cite this article:

doi: 10.5710/AMGH.19.03.2018.3170

PLEASE SCROLL DOWN FOR ARTICLE 
1 REDISCOVERED CRANIAL MATERIAL OF VENATICOSUCHUS RUSCONII

2 ALLOWS THE FIRST JAW BIOMECHANICS IN ORNITHOSUCHIDAE

3 (ARCHOSAURIA: PSEUDOSUCHIA)

4

5 M. BELÉN VON BACZKO ${ }^{1,2}$

6 'División Paleontología de Vertebrados, Museo de La Plata, Paseo del Bosque s/n

7 (B1900FWA), La Plata, Argentina.

$8 \quad{ }^{2}$ Consejo Nacional de Investigaciones Científicas y Técnicas (CONICET), Avenida

9 Rivadavia 1917 (C1033AAJ), Ciudad Autónoma de Buenos Aires, Argentina.

10 belen_vb13@yahoo.com.ar

11

1228 pages (text+references); 3 figures, 3 tables

13

14 Running header: BACZKO: JAW BIOMECHANICS IN ORNITHOSUCHIDS

15 Corresponding autor: M. Belén von Baczko 
Abstract. During the Triassic period, pseudosuchians had a wider variety of

17 feeding habits than those seen nowadays, including herbivorous, omnivorous, as well as carnivorous diets. Ornithosuchids have been historically proposed as either hunters or scavengers based on their general anatomy. The rediscovered cranial materials of the ornithosuchid Venaticosuchus described here in detail which allowed the reconstruction of its jaw musculature and a geometric biomechanic analysis was carried out to study the possible feeding habits of ornithosuchids. The muscles were reconstructed based on inferences of their osteological correlates seen in their closest living relatives such as Caiman, Alligator, and Iguana. Consequently, the jaws were considered as a third class lever system and the moment arms were calculated for the adductor and depressor musculature. The study of the three species of ornithosuchids (Ornithosuchus, Venaticosuchus, and Riojasuchus) revealed greater similarities between ornithosuchids and aetosaurs, despite having different feeding habits, than between ornithosuchids and crocodylians. The relative bite force of Venaticosuchus resulted higher than that of other ornithosuchids, aetosaurs and Alligator. The elevated bite force identified for ornithosuchids plus their low bite speed and the morphology of their constricted snouts suggest features more compatible to scavenging feeding habits. Ornithosuchids were not the apex predators of the Late Triassic continental communities but were more likely regarded to scavenging or preyed on small animals such as procolophonids, sphenodontians, juvenile aetosaurs, erpetosuchids, cinodonts, and dicynodonts that did not exceed them in size.

38 Keywords. Triassic, skull, paleobiology, ornithosuchids, Ischigualasto Formation, 39 Argentina 
Resumen. NUEVOS MATERIALES CRANEANOS DE VENATICOSUCHUS RUSCONII PERMITEN EL PRIMER ANALISIS DE BIOMECÁNICA MANDIBULAR EN ORNITHOSUCHIDAE (ARCHOSAURIA: PSEUDOSUCHIA).

43 Durante el período Triásico, los pseudosúquios presentaron una mayor variedad de

44 hábitos alimenticios que los que presentan hoy en día, incluyendo hábitos herbívoros, omnívoros y carnívoros. Los ornitosúquidos han sido propuestos históricamente como animales cazadores a carroñeros basados en su anatomía general. Los materiales craneanos redescubiertos del ornitosúquido Venaticosuchus descriptos aquí detalladamente han permitido la reconstrucción de su musculatura mandibular y un análisis biomecánico geométrico para evaluar su posibles hábitos alimenticios de los ornitosúquidos. Los músculos fueron reconstruidos con base en inferencias sobre sus correlatos óseos en sus parientes más cercanos como Caiman, Alligator e Iguana. . Las mandíbulas se consideraron como un sistema de palancas de tercer grado y se calcularon los brazos de palanca para cada músculo aductor y depresor. El estudio de las tres especies de ornitosúquidos (Ornithosuchus, Venaticosuchus y Riojasuchus) reveló mayores semejanzas entre estos y los aetosaurios, a pesar de sus diferentes hábitos alimenticios, que entre los ornitosúquidos y los crocodylios. La fuerza relativa de mordida de Venaticosuchus resultó ser mayor que las de los demás ornitosúquidos, los aetosaurios y Alligator. Ésta elevada fuerza de mordida de los ornitosúquidos, sumada a su baja velocidad de mordida, y asociado a la morfología de sus estrechos hocicos

60 aparentan ser características más compatibles con hábitos alimenticios carroñeros. Los

61 ornitosúquidos no habrían sido los mayores predadores de las comunidades continentales del Triásico Tardío, sino que estarían relegados a roles carroñeros o

63 predarían sobre pequeñas presas que no los superaran en tamaño como procolofónidos,

64 esfenodontes, y juveniles de aetosaurios, erpetosúquidos, cinodontes y dicinodontes. 
65 Palabras clave. Triásico, cráneo, paleobiología, ornitosúquidos, Formación

66 Ischigualasto, Argentina 
67 DURING the Triassic, pseudosuchian archosaurs occupied a wide variety of

68 paleobiological roles because of their diversity in body sizes, shapes, and feeding habits

69 (Sereno, 1991; Brusatte et al., 2010; Nesbitt, 2011). The variety of feeding habits of

70 Triassic pseudosuchians was much larger than those seen nowadays, being represented

71 by carnivorous forms like ornithosuchids, phytosaurs, gracilisuchids, rauisuchids, and

72 crocodylomorphs, as well as herbivorous and omnivorous forms such as aetosaurs, and

73 shuvosaurids (Desojo et al., 2013; Irmis et al., 2013; Nesbitt et al., 2013; Stocker and

74 Butler, 2013). Ornithosuchids in particular have been historically proposed as

75 carnivorous forms, either hunters or scavengers, based on their general anatomy

76 (Walker, 1964; Benton, 1983). These are a group of pseudosuchian archosaurs known

77 from continental deposits of the Late Triassic and registered along with aetosaurs,

78 rauisuchians, poposaurids and crocodylomorphs (Nesbitt, 2011; Butler et al., 2014).

79 They are carnivorous quadrupedal archosaurs with medium body sizes of about 2

80 metres long and have been registered only in present-day Argentina and Scotland. The

81 clade Ornithosuchidae currently comprises only three species: Ornithosuchus

82 woodwardi (Newton, 1894), Riojasuchus tenuisceps (Bonaparte, 1967), and

83 Venaticosuchus rusconii (Bonaparte, 1970). The first one is known from the

84 Lossiemouth Sandstones Formation, Moray, Scotland and the latter two from the

85 Ischigualasto-Villa Union Basin, La Rioja province, Argentina. Ornithosuchids have

86 very distinctive cranial features such as a strongly downturned premaxilla, a two-tooth

87 diastema between the premaxilla and maxilla, the lower jaws shorter than the skull, and

88 the presence of a palatine-pterygoid fenestra, among others (Sereno, 1991; Baczko and

89 Desojo, 2016). They have been proposed as having either carnivorous or scavenger

90 habits based on their general morphology (e.g., Walker, 1964, Benton, 1983), but only

91 the mechanical capabilities of Riojasuchus tenuisceps have been quantitatively tested 
with a finite elements analysis (Baczko et al., 2014b). The information required for this kind of study (e.i., CTscanns, virtual 3D models) was not currently available for the ornithosuchids Ornithosuchus woodwardi and Venaticosuchus rusconii,

Venaticosuchus rusconii was erected by Bonaparte (1970) based on a partial skull found in the Ischigualasto Formation (late Carnian-early Norian, Martinez et al. 2011) of La Rioja. This specimen was very briefly described and assigned to Ornithosuchidae for its general resemblance with Riojasuchus tenuisceps and Ornithosuchus woodwardi. Baczko et al. (2014a) carried out a detailed description of the holotype of Venaticosuchus rusconii and supported its affinity to Ornithosuchidae within a phylogenetic framework. In 2015, newly rediscovered skull elements of Venaticosuchus rusconii were found in the palaeontology collection of the Instituto Miguel Lillo (Tucuman, Argentina). These corresponded to the right side of the posterior region of the skull and right mandible of the holotype, which were figured but not described by Bonaparte (1970) and were also not described by Baczko et al. (2014a) because they were thought to be lost.

These newly rediscovered materials corresponding to the holotype of Venaticosuchus rusconii were here described in detail. The new anatomical information allowed the first reconstruction of the muscles of the adductor chamber and the study of the jaw biomechanics of ornithosuchids. The application of traditional biomechanic models in extinct taxa is a good approach to test functional hypotheses, such as feeding behaviour (Vizcaíno et al., 1998). During feeding, in the closing movement of the jaws, these act as a third class lever system in which the pivot is at the craniomandibular joint, the input force is provided by the jaw muscles, and the output force is produced by the teeth on food. This traditional biomechanical analysis is based on a first hand study of the specimens and bibliographical references. Under this biomechanical model, 
117 hypothesis about the feeding habits of Ornithosuchidae are put to test to try to

118 understand which role they occupied (scavenger or active predatory) in the continental

119 communities of the Late Triassic of Pangaea.

\section{MATERIAL AND METHODS}

This study was based on the holotype specimen of Venaticosuchus rusconii (PVL

122 2578) including the newly rediscovered cranial materials of the holotype found at

123 paleontology collection of the Instituto Miguel Lillo (Tucumán) that were described

124 here (quadrate, quadratojugal, surangular, articular, angular, prearticular). This

125 specimen was studied first hand and compared with the cranial material of the other

126 known ornithosuchids Riojasuchus tenuisceps (PVL 3827, 3828) and Ornithosuchus

127 woodwardi (NHMUK PV R 2409-2410, 3142, 3143, 3149, 3562) as well as a variety of

128 archosauriforms (proterochampsids, erpetosuchids), pesudosuchians (aetosaurs,

129 gracilisuchids, erpetosuchids, loricatans, crocodylomorphs), and dinosaurs (theropods,

130 sauropodomorphs, ornithischians) studied first hand and through bibliographic

131 references.

132 The reconstruction of all the mandibular adductor and depressor muscles of

133 Venaticosuchus rusconii was inferred from direct observation of living reptiles using the

134 Extant Phylogenetic Bracket approach (Witmer, 1995), because there are no clear

135 muscular attachment scars on the skull of this species. Using this method, the

136 attachment scars of the adductor and depressor muscles of Caiman yacare (MACN HE

137 48841) and Iguana iguana (MACN HE 42334), some of the closest living relatives of

138 ornithosuchids, were directly observed through dissection and used to infer the same

139 attachment areas in the fossil taxa studied. . The seven main muscles present in living

140 crocodylians were identified in ornithosuchids as well as the six main muscles present 
141 in Iguana (e.g., Bona and Desojo, 2011; Holliday and Witmer, 2007, Iordansky, 2000),

142 although the different parts that comprise each of these muscles cannot be differentiated

143 in ornithosuchids. The insertion area of the different parts of these muscles have subtle

144 variations within the extant taxa whose level of detail cannot be determined in

145 Venaticosuchus without the actual scars on the skull bones. All muscles were identified

146 with a Level I inference because they were present in both extant taxa, excepting the

147 intramandibular muscle which is present in Caiman but absent in Iguana and therefore

148 was reconstructed as a Level II inference (Witmer, 1995). Muscles were described by

149 comparison between Venaticosuchus rusconii and the other ornithosuchids, and the

150 correlation with their closest living relatives, crocodylians. The same muscular

151 reconstructions were made for Riojasuchus tenuisceps and Ornithosuchus woodwardi to

152 carry out the biomechanical analysis.

153 Jaw biomechanics were analysed based on the moment arms of the jaw

154 musculature of the three known species of ornithosuchids (Venaticosuchus rusconii,

155 Riojasuchus tenuisceps, and Ornithosuchus woodwardi). The moment arms of the lines

156 of action of the muscles can be estimated to analyse relationships between bite force and

157 bite velocity (Cassini and Vizcaíno, 2012). The moment arms of the reconstructed

158 musculature of ornithosuchids were estimated by the adaptation of the geometric model

159 carried out by Desojo and Vizcaíno (2009) for aetosaurs, which was based on the

160 models developed by Vizcaíno et al. (1998) for mammals. Desojo and Vizcaíno (2009)

161 reconstructed the jaw musculature of aetosaurs in detail comparing them with their

162 living relatives, crocodylians. In that study, the first quantitative biomechanical analysis

163 for pseudosuchians, the authors combined the moment arm of the external and posterior

164 adductor muscles (MAME + MAMP) because of their similar orientation, but in the

165 present study they were considered separately because the attachment areas could be 
166 indicated separately in ornithosuchids. The pterygoid muscles were also considered by

167 Desojo and Vizcaíno (2009) as a unique element for aetosaurs (MAMIPT = MPtD +

$168 \mathrm{MPtV}$ ) but here the pterygoid muscles are differentiated in their ventral and the dorsal

169 units for ornithosuchids, as in crocodylians and iguanas (Bona and Desojo, 2011;

170 Holliday and Witmer, 2007). The values of these pairs of muscles were combined later

171 only to allow comparing them with Desojo and Vizcaíno (2009) results for the

172 MAME+MAMP and MAMIPT. For the estimation of moment arms, total lengths of the

173 mandibles were standardized at the same length to remove the influence of size on the

174 comparisons between different species which had different sizes (Vizcaíno et al. 1998).

175 Therefore, measurements taken from the drawings of the skulls and the units are used

176 only in comparative terms independent of size of the species. The contribution of each

177 muscle was considered as its percentage over the sum of moment arm of the adductor

178 muscles $\left(\mathrm{X}^{*} 100 / \mathrm{AM}\right)$.

179 Institutional abbreviations. MACN HE, Colección Herpetología, Museo

180 Argentino de Ciencias Naturales "Bernardino Rivadavia”, Buenos Aires, Argentina;

181 NHMUK PV R, Natural History Museum, London, UK; PULR, Museo de

182 Paleontología, Universidad Nacional de La Rioja, La Rioja, Argentina; PVL,

183 Paleontología de Vertebrados, Instituto Miguel Lillo, Tucumán, Argentina; SMNS,

184 Staatliches Museum für Naturkunde, Stuttgart, Germany.

\section{SYSTEMATIC PALAEONTOLOGY}

ARCHOSAURIA Cope, 1869 sensu Gauthier and Padian, 1985 
Type species. Venaticosuchus rusconii Bonaparte, 1970

192 Type material. PVL 2578: Represented by an incomplete skull (lacking most of the

193 braincase and the skull roof) with both hemimandibles articulated. Bonaparte (1970)

194 reported an anterior limb and isolated osteoderms but these were neither described nor

195 figured and were later regarded as missing by Baczko and Ezcurra (2013). Recently, the

196 right side of the posterior region of the skull and lower jaw of the holotype were found

197 in the Vertebrate Palaeontology collection of the Instituto Miguel Lillo, Tucumán,

198 Argentina. This region corresponds to the right quadratojugal, quadrate, surangular,

199 angular, prearticular and articular, which had only been figured by Bonaparte (1970) but

200 not described. These elements have been regarded as missing until now and therefore

201 were not included in previous descriptions of Venaticosuchus rusconii (Baczko et al., 202 2014a; Baczko, 2017).

203 Diagnosis. Ornithosuchid archosaur that differs from the others by one local 204 autapomorphy: the absence of the surangular foramen. Venaticosuchus rusconii also 205 differs from other pseudosuchians by the following character state combination: (1) 206 basipterygoid processes ventrally projected, (2) articular without a foramen on its 207 medial surface, and (3) dentary dorsally expanded on its anterior tip. (Baczko et al., 208 2014a).

209 Geographic and stratigraphic occurence. Hoyada del Cerro Las Lajas, La Rioja.

210 Middle section of the Ischigualasto Formation (late Carnian-early Norian, Late Triassic;

211 Martinez et al., 2011). This locality has yielded two other archosaur specimens, the 212 holotype of the dinosaur Pisanosaurus mertii Casamiquela, 1967 (Casamiquela, 1967;

213 Bonaparte, 1976, Agnolín and Rozadilla, 2017), and the specimen PVL 3889 referred to 214 the crocodylomorph Trialestes romeri Reig, 1963 (Bonaparte, 1970, 1976, 1978, 
215 Lecuona et al., 2016). These outcrops have been regarded as equivalent to the middle

216 levels of the type section of the Ischigualasto Formation (Bonaparte, 1976, 1982). This

217 formation has been dated at its type locality by radioisotopic methods, yielding ages of

$218231 \pm 0.3$ Ma for its basal levels (Rogers et al., 1993; Furin et al., 2006) and $225.9 \pm 0.9$

219 Ma for its uppermost levels (Martinez et al., 2011). Therefore, the age of the sediments

220 from which PVL 2578 was recovered is considered as bracketed by these two dates on

221 the absence of more specific information about the Cerro Las Lajas area. Nevertheless,

222 the lateral correlation between the outcrops of Cerro Las Lajas and the type locality of

223 the Ischigualasto Formation proposed by Bonaparte (1976) cannot be determined with

224 certainty because there are no shared faunal components to support it (Baczko et al.,

225 2014a).

226 RESULTS

227 Comparative description of the newly rediscovered cranial material

228 The quadratojugal of Venaticosuchus ruconii (PVL 2578) is a mediolaterally

229 compressed, L-shaped element (Fig. 1.1: ITF, qj). The quadratojugal forms the ventral

230 half of the posterior margin of the infratemporal fenestra, unlike that of some aetosaurs

231 (e.g., Neoaetosauroides engaeus: PVL 5698, Aetosaurus ferratus: SMNS 5770),

232 loricatans (e.g., Batrachotomus kupferzellensis: SMNS 52970, Postosuchus kirkpatricki:

233 Weinbaum, 2011), and crocodylomorphs (e.g., Hesperosuchus agilis: Clark et al., 2000)

234 in which the quadratojugal delimits the entire posterior margin of such fenestra. The

235 quadratojugal also delimits the medial margin of the quadrate foramen, located between

236 the quadratojugal and the quadrate, although the suture between these two elements is

237 not clear in Venaticosuchus rusconii (Fig. 1.3: q.f). The anterior ends of the anterior and

238 dorsal processes are broken, therefore the articular facets for the jugal and the 
squamosal cannot be identified. The anterior process of the quadratojugal is anteroposteriorly oriented and tapers anteriorly. The dorsal process is anterodorsally directed with an inclination of $45^{\circ}$ from the horizontal plane and keeps the same width

242 along its entire length. The shape of the quadratojugal of Venaticosuchus rusconii and

243 its inclination would grant a distinctive L-shape to the infratemporal fenestra as seen in

244 other ornithosuchids (Riojasuchus tenuisceps: PVL 3827, 3828; Ornithosuchus

245 woodwardi: NHMUK PV R2409) (Fig. 1: ITF, qj). The infratemporal fenestra shape

246 seen in ornithosuchids resembles that of some proterochampsids (e.g., Chanaresuchus

247 bonapartei: PVL 4586 y Gualosuchus reigi: PULR 05) in which a concavity on the

248 posteroventral margin gives the fenestra a similar L-shape. The quadratojugal of

249 Venaticosuchus rusconii (PVL 2578) does not have an infratemporal fossa, as is also the

250 case of the other ornithosuchids Ornithosuchus woodwardi (NHMUK PV R2409) and

251 Riojasuchus tenuisceps (PVL 3827, 3828). The external surface of the quadratojugal of

252 Venaticosuchus rusconii is poorly preserved but no crests can be recognized on it, it is

253 convex and smooth without any kind of ornamentation as that seen in Ornithosuchus

254 woodwardi (NHMUK PV R3143). The posterior region of the skull of Venaticosuchus

255 rusconii was preserved in articulation with the lower jaw, which allows to see that the

256 quadratojugal lies on the dorsal surface of the surangular shelf when the mandibles

257 occlude (Fig. 1.1-3: qj, sa, sa.sh) as can also be recognized in Riojasuchus tenuisceps

258 (PVL 3827).

The right quadrate of Venaticosuchus rusconii (PVL 2578) is complete and was preserved in articulation with the quadratojugal and close to its natural articulation with

262 the mandible (Fig. 1.1-3: q, qj). The quadrate is posteroventrally directed like in most

263 archosaurs, excepting the aetosaurs (e.g., Neoaetosauroides engaeus: PVL 5698), the 
264 shuvosaurid Shuvosaurus inexpectatus, spinosaurid and ornithomimid dinosaurs in

265 which the quadrate is anteroventrally directed. The posteroventral inclination of the 266 quadrate of Venaticosuchus rusconii (PVL 2578) almost reaches $45^{\circ}$ above the

267 horizontal plane (Fig. 1.1, 2: q). This condition is quite rare within archosauriforms and 268 has only been registered in ornithosuchids (e.g., Riojasuchus tenuisceps, PVL 3827), 269 gracilisuchids (e.g., Gracilisuchus stipanicicorum: PULR 08, Yonghesuchus

270 sangbiensis: Wu et al., 2001), erpetosuchids (e.g., Erpetosuchus granti: Benton and 271 Walker, 2002, Tarjadia ruthae: CRILAR-Pv 478, 495), and some proterosuchids (e.g.,

272 Proterosuchus fergusi: Ezcurra y Butler, 2015). The quadrate of Venaticosuchus

273 rusconi (PVL 2578) delimits the medial half of the quadrate foramen which is round

274 and formed between the quadrate and the quadratojugal (Fig. 1.3: q.f). The suture

275 between these last two elements cannot be clearly recognized because of the poor 276 preservation of their external surface. The dorsal head of the quadrate is convex and

277 subtriangular in dorsal view and is slightly damaged on its lateral margin. The ventral

278 end of the quadrate has an anteromedially directed furrow on its distal surface that 279 divides this end into two condyles. The lateral condyle is twice as wide as the medial 280 condyle. The pterygoid process of the quadrate is fan-shaped, expanding anteroventrally 281 and forming a $90^{\circ}$ angle with the quadratojugal (Fig. 1.1, 2: q, qj). The quadrate of

282 Venaticosuchus rusconii is smooth on its posterior surface and unlike the ornithosuchid 283 Riojasuchus tenuisceps (PVL 3827) and some rauisuchids (e.g., Postosuchus

284 kirkpatricki: Weinbaum, 2011; Polonosuchus sileasicus: ZPAL Ab III 563) it does not 285 have a crest on its posterior surface.

The right surangular of Venaticosuchus rusconii is better preserved than the left 287 one previously described by Baczko et al. (2014a). This element is anteroposteriorly elongated, it delimits the posterodorsal margin of the external mandibular fenestra and 
the dorsal margin of the posterior half of the lower jaw (Fig. 1.1, 2: EMF, sa). It contacts the articular posteromedially and the angular ventrally at straight sutures. The good preservation of the right surangular of Venaticosuchus rusconii (PVL 2578) allowed the identification a well-developed surangular shelf that was not preserved on

293 the damaged left surangular. The surangular shelf is laterally projected forming a $90^{\circ}$

294 angle with the lateral surface of the bone (Fig. 1.1: sa.sh). This shelf would contact the

295 quadratojugal, as previously mentioned, when the mandibles occlude as can also be seen other archosaurs (e.g., Riojasuchus tenuisceps: PVL 3827, 3828; Gracilisuchus stipanicicorum: MCZ 4116, Tarjadia ruthae: CRILAR-Pv 478, 495). The surangular of Venaticosuchus rusconii (PVL 2578) does not have a surangular foramen resembling the condition of crocodylomorphs (e.g., Sphenosuchus acutus: Walker, 1990,

300 Dibothrosuchus elaphros: Wu and Chatterjee 1993, Caiman yacare: MACN HE 43694) but differing from all other archosauriforms in which the surangular foramen is present (e.g., Chanaresuchus bonapartei: PVL 4676, Euparkeria capensis: cast of SAM-PK 5867, Riojasuchus tenuisceps: PVL 3827, Aetosaurus ferratus: SMNS 5770, Effigia okeeffeae: Nesbitt, 2007). poorly preserved and offer no novel information about the anatomy of these elements.

307 Only the posterior portion of these elements was preserved and they are sutured to the 308 articular posteriorly and to the surangular posterodorsally (Fig. 1.1, 2: an, pre). The angular delimits the posteroventral margin of the external mandibular fenestra, whereas

310 the prearticular delimits the same margin of the internal mandibular fenestra. The suture

311 between the angular and the prearticular is straight and can be recognized on the ventral 312 margin of the hemimandible. Anterior to these bones, there is an internal mould that 
313 corresponds to the filling of the intramandibular space delimited by the angular and the

314 prearticular.

315 The articular is a short element; it is equally wide as long and has a triangular

316 shape in dorsal view. It forms the posterior end of the mandibles, contacts the

317 surangular anteriorly and the prearticular anteromedially. The retroarticular process is

318 poorly developed reaching half the length of the glenoid fossa (Fig. 1.1, 2: ar, ra.p). This

319 fossa is mediolaterally wide and concave. It is located on the same plane as the dorsal

320 margin of the mandible, unlike that of aetosaurs (e.g., Neoaetosauroides engaeus: PVL

321 4363), ornithischians (Heterodontosaurus tucki, Norman et al., 2011), and

322 sauropodomorphs (Plateosaurus erlenbergiensis, Prieto-Márquez and Norell, 2011),

323 which have the glenoid fossa located below the plane of the dorsal margin of the

324 mandible.

\section{Reconstruction of the jaw musculature}

The Musculus adductor mandibulae externus (MAME) of Venaticosuchus

rusconii was attached on the ventral surface of the quadrate and inserted on the dorsal

surface of the surangular filling part of the infratemporal fenestra (Fig . 2.1). The

direction and shape of the MAME differs from that of crocodylians because of the

330 orientation of the quadrate. The MAME of Venaticosuchus rusconii was posterodorsally

331 to anteroventrally oriented resembling the condition of Iguana iguana but fan-shaped

332 because its dorsal attachment area is anteroposteriorly short, differing from Caiman

333 latirostris and Alligator mississippiensis in which that muscle is almost dorsoventrally

334 oriented, straight and anteroposteriorly long. In the case of Venaticosuchus rusconii, the

335 quadrate is anterodorsally directed at $45^{\circ}$ from the horizontal plane, being more vertical

336 and not reaching the anterior extent of the surangular as in Iguana iguana, but unlike 
337 crocodylians that have a quadrate oriented at $35^{\circ}$ from the horizontal plane and therefore

338 projecting further anteriorly up to the same extent as the anterior end of the surangular

339 (Iordansky, 1973). In Venaticosuchus rusconii, the surface of the quadrate where this

340 muscle would attach is smooth and anteroposteriorly short, also differing from Caiman

341 latirostris and Caiman yacare, which have an anteroposteriorly larger area with a

342 longitudinal ridge on the ventral surface of this element for muscular attachment (Bona

343 and Desojo, 2011, fig. 4A-B).

$344 \quad$ [Place here Figure 2]

346 rusconii originated on the ventral surface of the quadrate, medial to the MAME, and

347 inserted on the dorsomedial surface of the angular and the medial surfaces of the

348 articular and surangular (Fig. 2.2). The medial surface of the surangular is gently

349 striated whereas no muscular attachment mark can be recognized on the surface of the

350 articular. This last insertion area is inferred using EPB approach, because of the

351 presence of the same structure in crocodylians and iguanas. The MAMP of

352 Venaticosuchus rusconii would fill the posterior half of the mandibular fenestra and,

353 together with the MAME, the infratemporal fenestra (Bona and Desojo, 2011). The

354 MAMP of Venaticosuchus rusconii was dorsoventrally oriented resembling the

355 condition of crocodylians and iguanids (e.g., Caiman latirostris, Caiman yacare,

356 Alligator mississippiensis, and Iguana iguana).

The Musculus pterygoideus dorsalis (MPtD) was attached to the dorsal surface of

358 the palate and covered the posterior surface of the mandible inserting on the

359 posteromedial corner of the articular and angular. The Musculus pterygoideus ventralis

360 (MPtV) was attached on the posterodorsal region of the pterygoid and inserted on the 
361 posterolateral side of the angular and articular covering the posterior region of the

362 mandible (Fig. 2.3, 4). Both these muscles would have an almost anteroposteriorly

363 orientation, which differs from the posterolateral direction seen in crocodylians. In

364 Venaticosuchus the MPtD and MPtV barely project laterally because its skull is higher

365 and laterally compressed compared to that the skull of crocodylians which is depressed

366 and wide (Caiman latirostris, Caiman yacare, Alligator mississippiensis).

367 The dorsal insertion area of the Musculus pseudotemporalis (MPst) was not

368 preserved in Venaticosuchus rusconii but was inferred by comparison with its sister taxa

369 Riojasuchus tenuisceps. In crocodylians as Caiman and Alligator it attaches to the

370 lateral surface of the laterosphenoid although in iguanids it attaches to the ventrolateral

371 margin of the parietal because they do not have a laterosphenoid. As Venaticosuchus

372 has laterosphenoid it would be attached to that same element located anterodorsally to

373 the basal tubera (Fig. 2.5). The ventral insertion of the MPst was on the dorsolateral

374 buttress of the pterygoid as seen in crocodylians and differing from iguanids in which it

375 attaches to the coronoid process of the mandible. The MPst of Venaticosuchus would be

376 slightly posterodorsally oriented differing from the dorsoventral orientation that this

377 muscles has in crocodylians and iguanids.

The Musculus intramandibularis (MI) of Venaticosuchus rusconii was attached

on the pterygoid buttress. In iguanids this muscles is absent, but crocodylians it forms a

380 sesamoid element, the transiliens cartilage, where it contacts the Musculus

381 pseudotemporalis (Tsai and Holliday, 2011), but there is no evidence of this cartilage in

382 ornithosuchids. The MI of Venaticosuchus would insert on the medial surface of the

383 dentary and lateral surface of the splenial, filling the Meckelian canal and the anterior

384 half of the external mandibular fenestra (Fig. 2.6). 

rusconii would have a different dorsal attachment area than that of crocodylians and

387 iguanids because the supraoccipital, parietal, and squamosal of ornithosuchids do not

388 have such exposure at the occipital table as that seen in the former (e.g., Alligator

389 mississippiensis and Caiman latirostris, Baczko and Desojo, 2016: fig 5; Bona and

390 Desojo, 2011: fig. 2D; Iguana iguana: MACN HE 42334). Although the supraoccipital 391 and squamosal are not preserved in Venaticosuchus rusconii, in other ornithosuchids (e.i., Riojasuchus tenuiscep: PVL 3827, Ornithosuchus woodwardi: NHMUK PV R2409) the supraoccipital is a flat anterodorsally directed element and the squamosals

394 do not have a posterior exposure, therefore there is no attachment surface available for

395 the MDM in these elements. The MDM would probably be dorsally attached to the 396 posterior surface of the exoccipital and the paroccipital process (Fig. 2.7), although these elements were not preserved in Venaticosuchus rusconii, they can be seen in its sister taxon Riojasuchus tenuisceps (PVL 3827) as reference. The posterodorsal surface

399 of the quadrate is also part of the attachment area for the MDM. The quadrate of

400 Venaticosuchus rusconii was preserved complete allowing a partial interpretation on the 401 MDM disposition. This muscle would insert on the dorsal surface of the retroarticular process of the articular and is posteroventrally to anterodorsally oriented (Fig. 2.7). The MDM of Venaticosuchus rusconii would be more dorsoventrally oriented $\left(60^{\circ}\right)$ than that of Caiman latirostris and Caiman yacare $\left(45^{\circ}\right.$, Bona and Desojo, 2011) because in the

405 former the quadrate is more vertical and the retroarticular process is shorter. In occipital 406 view, the MDM of Venaticosuchus rusconii would be much more vertical compared to 407 crocodylians because the skull is higher and more laterally compressed than the 408 depressed and wide skulls of crocodylians. 
411 The moment arms were calculated for the Musculus adductor mandibulae externus

412 (MAME); Musculus adductor mandibulae posterior (MAMP), Musculus pterygoideus

413 dorsalis (MPtD), Musculus pterygoideus ventralis (MPtV), Musculus pseudotemporalis

414 (MPst), Musculus intramandibularis (MI), Musculus depressor mandibulae (MDM) of

415 ornithosuchids and Alligator (Tab. 1). Even though the extant taxon Iguana iguana was

416 used for the EPB approach to reconstruct the muscular apparatus, it was not considered

417 for the biomechanical analysis. Iguanids have kinetic skulls and their feeding mechanics

418 are different to that of ornithosuchids which have akinetic skulls. From a biomechanical

419 point of view, the skull of crocodylians is best for comparative purposes because they

420 work the same way as that of ornithosuchids because they are both akinetic structures.

In ornithosuchids, the MPst and MI represent the largest contribution to the total adductor musculature (24-29\%) whereas the MPtD and MPtV have the lowest participation (7-11\%) (Tab. 1). In Venaticosuchus the dominant muscle is the MPst, differing from Riojasuchus and Ornithosuchus in which the main input is made by the MI. The ratio of total arm moment to bite moment is remarkably highest in Venaticosuchus, being approximately a 30\% lower in Riojasuchus and Ornithosuchus and a $70 \%$ lower in Alligator.

[Place here Table 1]

DISCUSSION

The sum of moment arms of the adductor muscles (AM) is similar within the

432 ornithosuchids, with Venaticosuchus representing the highest AM and Ornithosuchus

433 the lowest AM, 16\% below Venaticosuchus. The difference of Alligator with 
434 ornithosuchids is much higher, with the AM of Alligator being a $25 \%$ below the value

435 of Venaticosuchus (Tab. 1). The AM of ornithosuchids resembles that of aetosaurs

436 which according to Desojo and Vizcaíno (2009) are a 20\% higher than Alligator. This

437 resemblance is probably a reflection of the skull shape of this terrestrial Triassic species

438 which is much higher and shorter than skull of living semiaquatic crocodylians. The

439 distribution of the adductor muscles in the high and short skulls of the fossil taxa is

440 more dorsoventrally oriented and generates higher moment arm than the more

441 anteroposteriorly inclined adductor muscles of the depressed and elongate skulls of

442 crocodylians (e.g., MAMP, MI). The elevated moment arm of the adductor muscles of

443 these terrestrial species is probably related to higher masticatory needs of these animals.

444 A resemblance to this condition can be seen within living crocodylians, in which the

445 long-snouted species (e.g., Gavialis gangeticus) have more reduced pterygoid muscles

446 compared to the short-snouted species (e.g., Alligator mississippiensis) which is

447 associated to a lower masticatory power in the long-snouted species that have more

448 specialized fish-eating diets (Endo et al., 2002).

449 When comparing the input of each muscle among the three species of

450 ornithosuchids, it can be seen that the highest participation of both mandibular adductor

451 muscles (MAME: 18.5\% and MAMP: 11.5\%) is in Riojasuchus (Tab. 1). This could be

452 due to the anteroposterior distance between the craniomandibular articulation and the

453 posterior end of the skull roof, where these muscles are dorsally attached. This distance

454 is slightly larger in Riojasuchus than in other ornithosuchids, therefore the moment arm

455 is the highest in this species. On the contrary, when the distance between the

456 craniomandibular articulation and the posterior end of the skull roof is shorter, the

457 moment arm value decreases, as it can be seen in the ornithosuchids Venaticosuchus

458 (MAME+MAMP: 24.3\%) and Ornithosuchus (23.2\%) and the aetosaurs 
460 2). Aetosaurs particularly, have the posterior region of the skull almost antroposteriorly

461 aligned with the craniomandibular joint and probably for that reason the values of

462 participation of the MAME and MAMP are the lowest among the pseudosuchians

463 analyzed (i.e., Neoaetosauroides, Stagonolepis).

[Place here Table 2]

465

The participation of the pterygoid muscles (MPtD and MPtV) to the total AM is higher in Ornithosuchus (15.6\% and $13.8 \%$ respectively) than in the other ornithosuchids (7.7-10.5\%) (Tab. 1). This difference could be given by the peculiar shape of the surangular of Ornithosuchus which is oddly high compared to that of Riojasuchus and Venaticosuchus. This high surangular increases the distance between the craniomandibular joint and the ventral attachment of the pterygoid muscles and therefore their arm moment. This condition resembles that of crocodylians like Alligator which has proportionally high surangular, with MPtD and MPtV values (11\% and 9\% respectively) slightly lower than Ornithosuchus. The results obtained for Riojasuchus and Venaticosuchus (MPtD+MPtV: 17.7-20.2\%) represented an intermediate value between 475 Alligator and aetosaurs (Tab. 2), which have lower participation of the pterygoid muscles 476 (MPtD+MPtV: 11-16\%), and also have low surangulars. 478 slightly higher in Venaticosuchus and Riojasuchus (26.2\% and 27.7\%) than in 479 Ornithosuchus (24.1\%) (Tab. 1). The values obtained for the former are closer to that of 480 Alligator (34\%) but are lower than that presented for aetosaurs (30.9-34.1\%). On the 481 other hand, the participation of the intramandibular muscle (MI) is higher in 482 Venaticosuchus (29.2\%) than in other ornithosuchids (23.2-24.6\%), but it is surpassed by 
that of aetosaurs (30.9-34.1\%) (Tab. 2). Considering the contribution of these last two

484 muscles (MPst and MI) to the total moment arm (AM) it is noticeable that in 485 Venaticosuchus the largest contribution to the AM is made by the MI, while in 486 Riojasuchus and Ornithosuchus it is made by the MPst (Tab. 1). This could be explained 487 by the robustness of the mandible of Venaticosuchus which is much higher than that of 488 other ornithosuchids. For instance, the mandible of the Venaticosuchus is 5.6 times longer 489 than high, contrasting with the other ornithosuchids which have more slender mandibles, 4908 to 8.8 times longer than high. This difference in shape of the mandible would be 491 reflected in the distribution of the intramandibular musculature and consequently in the 492 moment arm of said muscles. The MI as a dominating input of the AM is also recognized 493 in the aetosaurs Stagonolepis and Desmatosuchus (Tab. 2) which also have high 494 mandibles with proportions similar to that of Venaticosuchus, 5 to 6 times longer than 495 high. In these species the MI represents the $31.7-34.9 \%$ of the AM, reaching a value even 496 higher than that of Venaticosuchus rusconii. On the other hand, in crocodylians such as 497 Alligator mississippiensis, the largest contribution to the AM is given by the MPst (34\%) 498 as in the ornithosuchids Riojasuchus tenuisceps and Ornithosuchus woodwardi.

499 The moment arm of the mandibular depressor muscle (MDM) is higher in 500 Riojasuchus than in other ornithosuchids, but that input is 1.6 times lower than that of 501 Alligator (Tab. 1). This difference is probably because the retroarticular process of 502 ornithosuchids, where the MDM inserts, is very short whereas that of Alligator is much more posteriorly expanded. On the other hand, the moment arm of the MDM is even

504 larger in aetosaurs, reaching values that triple the MDM moment arm of ornithosuchids 505 (Tab. 2). Aetosaurs have a well-developed retroarticular process that, unlike in any 506 other pseudosuchian, is located below the dorsal level of the mandible, as in many 
507 herbivorous animals, an important factor that possibly increases the moment arm of the 508 MDM.

The bite moment was analyzed on the first $(\mathrm{Mb} 1)$ and last $(\mathrm{Mb} 2)$ maxillary teeth

510 and on the first dentary tooth (Mb3). The dentary tooth position could not be considered

511 in Venaticosuchus because its dental configuration is different to that of the other

512 ornithosuchids. On one hand, the first two dentary teeth of Venaticosuchus are

513 hypertrophied and do not occlude with the premaxillary teeth because they fit into an

514 edentulous diastema. Then again, Venaticosuchus does not have a first small tooth that

515 occludes with the premaxilla, anterior to those hypertrophied ones, unlike that seen in

516 Riojasuchus and Ornithosuchus (Baczko et al., 2014a; Baczko and Desojo, 2016). The

517 values here obtained for the bite moment of Alligator were slightly different to those

518 obtained by Desojo and Vizcaíno (2009). This difference might represent intraspecific

519 variation and therefore these values were combined to obtain an average value for the

520 taxon to be able to compare with their results.

The ratios $(\mathrm{R})$ of total arm moments $(\mathrm{AM})$ to bite moment $(\mathrm{Mb})$ revealed much

522 higher values in ornithosuchids than in the crocodylian Alligator, resulting in a bite

523 force $31-74 \%$ stronger in ornithosuchids (Tab. 3). When comparing with the bite ratios

524 here estimated for the aetosaurs studied by Desojo and Vizcaíno (2009), it is remarkable

525 that Desmatosuchus reported a value between that of ornithosuchids and Alligator (Tab.

526 3), while Stagonolepis and Neoaetosauroides had values below Alligator. The high bite

527 ratio of Desmatosuchus was interpreted by Desojo and Vizcaíno (2009) as a strong

528 biting force which, according to their dental morphology, would be better for crushing

529 and chopping their food. But in the case of ornithosuchids, the strong bite ratios

530 obtained here combined with the laterally compressed and serrated teeth and their

531 laterally constricted snout would indicate better capacities of slicing and tearing their 
532 food. The bite of ornithosuchids was probably slower than that of Alligator, as also

533 identified for herbivorous aetosaurs (Desojo and Vizcaíno, 2009), because the input

534 forces and the craniomandibular articulation of their mandibular lever system are more

535 distant from each other. Despite having a strong bite, the low speed inferred for

536 ornithosuchids would not support hunting abilities as those interpreted for the

537 animalivorous aetosaur Neoaetosauroides (Desojo and Vizcaíno, 2009), whose low bite

538 force was compensated by its velocity, as a fast bite is crucial for catching small preys.

539 Therefore, the relatively strong but slow bite of ornithosuchids seems more appropriate

540 for animals with scavenger habits, which do not require speed to catch a moving prey

541 and only need their strength for tearing flesh or crushing bones of a carcase.

$542 \quad$ [Place here Table 3]

543 The stronger adductor musculature of Venaticosuchus was accompanied by a slow

544 mandibular lever system resulting in relatively strong and slow bite movements.

545 Although this could be associated to an active predatory habit other factors need to be

546 considered. Particularly, the skull of ornithosuchids has a weak spot on their laterally

547 constricted snout (Baczko et al., 2014b) that would not resist high lateral stresses like

548 those applied by living prey trying to escape. Moreover, the laterally compressed teeth

549 of ornithosuchids are useful for tearing the flesh of a prey in an anteroposterior direction

550 but structurally weak in lateral direction, unlike the conical caniniform teeth of

551 crocodylians (e.g., Caiman, Alligator) that equally resist stresses in every direction and

552 hunt their living prey directly biting them. Considering this feaures, it is more likely that

553 ornithosuchids resorted to scavenging habits to avoid strong lateral stresses that may

554 occur while holding a prey that tries to escape and therefore prevent damaging

555 themselves. 

provided new information about some regions poorly known for this species and supported the local autapormorphy proposed by Baczko et al. (2014a), the absence of a surangular foramen.

The jaw biomechanics of ornithosuchids revealed more similarities between these and herbivorous aetosaurs, despite having different feeding habits, than with crocodylians who are also carnivorous as ornithosuchids. The overall resemblance in the skull shape between ornithosuchids and aetosaurs probably emphasized the phylogenetic distance that separates these basal pseudosuchians from their long-snouted 566 living relatives, crocodylians. ornithosuchids (e.g., mandibles proportionally higher) and this was reflected its muscular distribution. In this study, the intramandibular muscle (MI) represented the dominating element of the adductor musculature of this species, whereas in Riojasuchus, Ornithosuchus and crocodylians the main input is given by the pseudotemporal muscle (MPst). The condition seen in Venaticosuchus is also shared by

573 the aetosaurs Desmatosuchus and Stagonolepis, and moreover, its robust mandibular

574 configuration resembles that of aetosaurs more than that of its nearest relatives

575 Riojasuchus and Ornithosuchus.

577 ornithosuchids resembles the situation of Desmatosuchus amongst aetosaurs. Despite their different feeding habits, with the first being carnivorous and the second strictly herbivorous, both presented elevated bite forces probably because their premaxillae do 
not participate in the bite. In Venaticosuchus this condition is given because the

581 premaxillary teeth do not reach the mandibles when they occlude and the anterior-most dentary teeth fit into a diastema, whereas in Desmatosuchus it is given by the complete absence of premaxillary teeth. In both cases, their bite restricted to the maxillary region and therefore is stronger than in others because the bite force is not dissipated up to the premaxilla.

Both scavenger and active predator habits have been previously proposed for ornithosuchids based on different sources of information. Benton (1983) reported bitemarks on the middle-sized rhynchosaur Hyperodapedon (1.5 meters long) and assigned Ornithosuchus as the scavenger that produce these marks because this was the largest carnivore known for the Late Triassic of Scotland. On the other hand, Walker (1964) interpreted that Ornithosuchus "fulfils the role of a large predatory form" based on its morphology (e.g., jaws with curved teeth, forelimbs shorter than hind limbs, possible bipedalism), but mainly based on its large size. Nevertheless, it is important to note that,

594 at that time, Ornithosuchus was interpreted as a rather large carnivore of approximately 4 meters long, but considering the latest taxonomic revision of Baczko and Ezcurra (2016), Ornithosuchus would have actually been much smaller, no longer than 2 meters.

597 Following this interpretation with Ornithosuchus being more even in size with its

598 putative prey Hyperodapedon, it is more likely that the former left bite marks on the

599 bones of the latter while scavenging. Actively hunting on a prey of its same size, as 600 proposed by Walker (1964), could have resulted harmful on the snout of an 601 ornithosuchid if lateral stresses were applied while said prey tried to escape, as 602 previously discussed. Alternatively, ornithosuchids might have resorted to different 603 hunting strategies such as overthrowing and holding medium to small-sized prey (e.g., procolophonids, sphenodontians, cynodonts or juvenile dicynodonts) with their 
605 forelimbs before biting to prevent lateral stresses on their snout. However, this strategy

606 would have depended on their bipedal ability, and such locomotive capabilities are still

607 to be tested on ornithosuchids.

608 Considering the biomechanical information here obtained plus the anatomical and 609 structural data known for different ornithosuchids, they are here proposed as having

610 scavenger habits instead of being active predators because of their relatively strong and

611 slow bite and the structural weakness of their snout. Ornithosuchids did not occupy the

612 niche of apex predators of the Late Triassic continental communities but were more

613 likely regarded to scavenging the prey hunted by others or preyed on small animals such

614 as procolophonids, sphenodontians, juvenile aetosaurs, erpetosuchids, cinodonts, and

615 dicynodonts that did not exceed them in size.

\section{ACKNOWLEDGMENTS}

617 I thank J. Powell and L. Steel for granting me access to the materials studied. J.

618 Desojo, P. Bona, and J.R.A. Taborda for their suggestions on earlier versions of the

619 manuscript. I thank S. Nesbitt and an anonymous reviewer for their suggestions that

620 improved the quality of the manuscript. This study was partially funded by the Agencia

621 Nacional de Promoción Científica y Técnica (PICT 2014-609).

\section{REFERENCES}

623 Agnolín, F. L., and Rozadilla, S. 2017. Phylogenetic reassessment of Pisanosaurus

624 mertii Casamiquela, 1967, a basal dinosauriform from the Late Triassic of Argentina. Journal of Systematic Palaeontology 15: 1-27.

626 Baczko, M. B. von. 2017. [Revisión anatómica y estatus filogenético de la Familia Ornithosuchidae (Archosauria: Pseudosuchia) del Triásico Superior de Argentina 
y Escocia. Tesis doctoral. Facultad de Ciencias Exactas y Naturales, Universidad de Buenos Aires, 338 p. Unpublished.]

Baczko, M. B. von, and Desojo, J. B. 2016. Cranial anatomy and palaeoneurology of the archosaur Riojasuchus tenuisceps from the Los Colorados Formation, La Rioja, Argentina. PloS one 11: e0148575.

Baczko, M. B. von, Desojo, J. B., and Pol, D. 2014a. Anatomy and phylogenetic position of Venaticosuchus rusconii Bonaparte, 1970 (Archosauria, Pseudosuchia), from the Ischigualasto Formation (Late Triassic), La Rioja, Argentina. Journal of Vertebrate Paleontology 34: 1342-1356.

Baczko, M. B. von, and Ezcurra, M. D. 2013. Ornithosuchidae: a group of Triassic archosaurs with a unique ankle joint. Geological Society, London, Special Publications 379: 187-202.

Baczko, M. B. von, and Ezcurra, M. D. 2016. Taxonomy of the archosaur Ornithosuchus: reassessing Ornithosuchus woodwardi Newton, 1894 and Dasygnathoides longidens (Huxley 1877). Earth and Environmental Science Transactions of The Royal Society of Edinburgh 106: 199-205.

Baczko, M.B. von, Taborda, J.R.A., and Desojo, J.B. 2014b. First biomechanical analysis on the skull of the ornithosuchid Riojasuchus tenuisceps Bonaparte 1967 from the Los Colorados Formation, Late Triassic of Argentina. XXVIII Jornadas Argentinas de Paleontología de Vertebrados, Neuquen, Argentina. Ameghiniana, Suplemento Resúmenes 51: 23R. 
649 Benton, M. J. 1983. The Triassic reptile Hyperodapedon from Elgin: functional morphology and relationships. Philosophical Transactions of the Royal Society B: Biological Sciences 302: 605-718.

Benton, M. J., and Walker, A. D. 2002. Erpetosuchus, a crocodile-like basal archosaur from the Late Triassic of Elgin, Scotland. Zoological Journal of the Linnean Society 136: $25-47$.

Bona, P., and Desojo, J. B. 2011. Osteology and cranial musculature of Caiman

656 latirostris (Crocodylia: Alligatoridae). Journal of Morphology 272: 780-795.

Bonaparte, J. F. 1967. Dos nuevas "faunas" de reptiles triásicos de Argentina. Gondwana Symposium Proceedings and Papers 1: 283-306.

Bonaparte, J. F. 1970. Annotated list of the South American Triassic tetrapods. Gondwana Symposium Proceedings and Papers 2: 665-682.

Bonaparte, J. F. 1976. Pisanosaurus mertii Casamiquela and the origin of the 662 Ornithischia. Journal of Paleontology 50: 808-820.

663 Bonaparte, J. F. 1978. El Mesozoico de América del Sur y sus tetrápodos. Opera 664 Lilloana 26: 1-596

Bonaparte, J. F. 1982. Faunal replacement in the Triassic of South America. Journal of 666 Vertebrate Paleontology 2: 362-371.

667 Brusatte, S. L., Benton, M. J., Lloyd, G. T., Ruta, M., and Wang, S. C. 2010. 668 Macroevolutionary patterns in the evolutionary radiation of archosaurs 

Royal Society of Edinburgh 101: 367-382.

671 Butler, R. J., Sullivan, C., Ezcurra, M. D., Liu, J., Lecuona, A., and Sookias, R. B. 2014.

672

673

674

675

676

677

678

679

680

681

682

683

684

685

686

687

688

689

690
New clade of enigmatic early archosaurs yields insights into early pseudosuchian phylogeny and the biogeography of the archosaur radiation. BMC Evolutionary Biology 14: 128.

Casamiquela, R. M. 1967. Un nuevo dinosaurio ornitisquio Triásico (Pisanosaurus mertii; Ornithopoda) de la Formación Ischigualasto, Argentina. Ameghiniana 5: $47-64$.

Cassini, G. H., and Vizcaíno, S. F. 2012. An approach to the biomechanics of the masticatory apparatus of early miocene (Santacrucian age) South American ungulates (Astrapotheria, Litopterna, and Notoungulata): moment arm estimation based on 3D landmarks. Journal of Mammalian Evolution 19: 9-25.

Clark, J. M., Sues, H. D., and Berman, D. S. 2000. A new specimen of Hesperosuchus agilis from the Upper Triassic of New Mexico and the interrelationships of basal crocodylomorph archosaurs. Journal of Vertebrate Paleontology 20: 683-704.

Cope, E. D. 1869. Synopsis of the extinct Batrachia and Reptilia of North America. Transactions of the American Philosophical Society 14: 1-252.

Desojo, J. B., Heckert, A. B., Martz, J. W., Parker, W. G., Schoch, R. R., Small, B. J., and Sulej, T. 2013. Aetosauria: a clade of armoured pseudosuchians from the Upper Triassic continental beds. Geological Society, London, Special Publications 379: 203-239. 
691 Desojo, J. B., and Vizcaíno, S. F. 2009. Jaw biomechanics in the South American 692 aetosaur Neoaetosauroides engaeus. Paläontologische Zeitschrift 83: 499.

693 Endo, H., Aoki, R., Taru, H., Kimura, J., Sasaki, M., Yamamoto, M., Arashima, K., and 694 Hayashi, Y. 2002. Comparative functional morphology of the masticatory apparatus in the long-snouted crocodiles. Anatomia, Histologia, Embryologia 31:

697 Ezcurra, M. D., and Butler, R. J. 2015. Post-hatchling cranial ontogeny in the Early 698 Triassic diapsid reptile Proterosuchus fergusi. Journal of Anatomy 226: 387-402.

699 Furin, S., N. Preto,M. Rigo,G. Roghi, P. Gianolla, J. L. Crowley, and S.A. Bowring. 700 2006. High-precision U-Pb zircon age from the Triassic of Italy: implications for the Triassic time scale and the Carnian origin of calcareous nannoplankton and

Gauthier, J. and Padian, K. 1985. Phylogenetic, functional, and aerodynamic analyses of 704 dinosaurs. Geology 34: 1009-1012.

Holliday, C. M., and Witmer, L. M. 2007. Archosaur adductor chamber evolution: integration of musculoskeletal and topological criteria in jaw muscle homology. Journal of Morphology 268: 457-484.

Huene, F. von. 1908. Die Dinosaurier der europaiischen Triasformation mit Berticksichtigung der aussereuropdiischen Vorkomnisse. Geologische und Palaeontologische Abhandlungen 1: 1-419. 
713 Iordansky, N. N. 2000. Jaw muscles of the crocodiles: structure, synonymy, and some

714 implications on homology and functions. Russian Journal of Herpetology 7: 41$715 \quad 50$.

716 Irmis, R. B., Nesbitt, S. J., and Sues, H. D. 2013. Early Crocodylomorpha. Geological 717 Society, London, Special Publications 379: 275-302.

718 Lecuona, A., Ezcurra, M. D., and Irmis, R. B. 2016. Revision of the early crocodylomorph Trialestes romeri (Archosauria, Suchia) from the lower Upper Triassic Ischigualasto Formation of Argentina: one of the oldest known crocodylomorphs. Papers in Palaeontology 2: 585-622.

722

723

724

Martinez, R. N., Sereno, P. C., Alcober, O. A., Colombi, C. E., Renne, P. R., Montañez, I. P., and Currie, B. S. 2011. A basal dinosaur from the dawn of the dinosaur era in southwestern Pangaea. Science 331: 206-210.

Nesbitt, S. 2007. The anatomy of Effigia okeeffeae (Archosauria, Suchia), theropod-like convergence, and the distribution of related taxa. Bulletin of the American Museum of Natural History 302: 1-84.

Nesbitt, S. J. 2011. The early evolution of archosaurs: relationships and the origin of major clades. Bulletin of the American Museum of Natural History 352: 1-292.

Nesbitt, S. J., Brusatte, S. L., Desojo, J. B., Liparini, A., De França, M. A., Weinbaum, J. C., and Gower, D. J. 2013. Rauisuchia. Geological Society, London, Special Publications 379: 241-274. 
733 Newton, E. T. 1894. Reptiles from the Elgin Sandstone. Description of two new genera. Philosophical Transactions of the Royal Society of London B: Biological Sciences 185: 573-607.

Norman, D. B., Crompton, A. W., Butler, R. J., Porro, L. B., and Charig, A. J. 2011. The Lower Jurassic ornithischian dinosaur Heterodontosaurus tucki Crompton and Charig, 1962: cranial anatomy, functional morphology, taxonomy, and relationships. Zoological Journal of the Linnean Society 163: 182-276.

Prieto-Márquez, A., and Norell, M. A. 2011. Redescription of a nearly complete skull of Plateosaurus (Dinosauria: Sauropodomorpha) from the Late Triassic of Trossingen (Germany). American Museum Novitates 3727: 1-58.

Reig, O. A. 1963. La presencia de dinosaurios saurisquios en los "Estratos de Ischigualasto", (Mesotriásico superior) de las provincias de San Juan y La Rioja (República Argentina). Ameghiniana 3: 3-20.

Rogers, R. R., C. C. Swisher III, P. C. Sereno, A. M. Moneta, C. A. Forster, and R. N. Martinez. 1993. The Ischigualasto tetrapod assemblage (Late Triassic, Argentina) and 40Ar/39Ar dating of dinosaur origins. Science 260: 794-797.

Sereno, P. C. 1991. Basal archosaurs: phylogenetic relationships and functional implications. Journal of Vertebrate Paleontology 11: 1-53.

Stocker, M. R. and Butler, R. J. 2013. Phytosauria. Geological Society, London, Special Publications 379: 91-117.

Tsai, H. P., and Holliday, C. M. 2011. Ontogeny of the alligator cartilago transiliens and its significance for sauropsid jaw muscle evolution. PLoS One 6: e24935. 
755 Vizcaíno, S. F., De Iuliis, G., and Bargo, M. S. 1998. Skull shape, masticatory apparatus, and diet of Vassallia and Holmesina (Mammalia: Xenarthra: Pampatheriidae): when anatomy constrains destiny. Journal of Mammalian Evolution 5: 291-322.

Walker, A. D. 1964. Triassic reptiles from the Elgin area: Ornithosuchus and the origin of carnosaurs. Philosophical Transactions of the Royal Society of London B: Biological Sciences 248: 53-134.

Walker, A. D. 1990. A revision of Sphenosuchus acutus Haughton, a crocodylomorph reptile from the Elliot Formation (late Triassic or early Jurassic) of South Africa. Philosophical Transactions of the Royal Society of London B: Biological Sciences

Witmer, L. M. 1995. The extant phylogenetic bracket and the importance of 330: $1-120$.

Weinbaum, J. C. 2011. The skull of Postosuchus kirkpatricki (Archosauria: Paracrocodyliformes) from the Upper Triassic of the United States. PaleoBios 30: $18-44$.

Wu, X. C., and Chatterjee, S. 1993. Dibothrosuchus elaphros, a crocodylomorph from the Lower Jurassic of China and the phylogeny of the Sphenosuchia. Journal of Vertebrate Paleontology 13: 58-89.

Wu, X., Liu, J., and Li, J. 2001. The anatomy of the first archosauriform (Diapsida) from the terrestrial Upper Triassic of China. Vertebrata PalAsiatica 39: 251-265. 
777 Zittel, K., von 1887-1890. Handbuch der Paläontologie. Abteilung 1. Paläozoologie

778 Band III. Vertebrata (Pisces, Amphibia, Reptilia, Aves). Oldenbourg, Munich and 779 Leipzig, Germany, 900p. 
781 Figure 1. New cranial elements of Venaticosuchus rusconii in 1, lateral view; 2, medial view; and 3, posterior view. Abbreviations: an, angular; ar, articular; EMF, external mandibular fenestra; gl, glenoid fossa; ITF, infratemporal fenestra; pre, prearticular; q, quadrate; q.f, quadrate foramen; qj, quadratojugal; ra.p, retroarticular process; sa, surangular; sa.sh, surangular shelf. Scale bar= $20 \mathrm{~mm}$.

Figure 2. Dorsal (purple/dashed) and ventral (green/dotted) attachment areas of the adductor and depressor muscles of Venaticosuchus rusconii. 1, Musculus adductor mandibulae externus; 2, Musculus adductor mandibulae posterior; $\mathbf{3}$, Musculus pterygoideus dorsalis; 4, Musculus pterygoideus ventralis; 5, Musculus pseudotemporalis; 6, Musculus intramandibularis; and 7, Musculus depressor mandibulae. Dash-lines represent the reconstructed margins of incomplete elements, reconstruction based on PVL 2578 and the complete skull of its sister taxa Riojasuchus tenuisceps (PVL 3827). Scale bar= $50 \mathrm{~mm}$.

Figure 3. Moment arms and action lines of the adductor and depressor muscles of 1-7, Venaticosuchus rusconii; 8-14, Riojasuchus tenuisceps; 15-21, Ornithosuchus woodwardi; and 22-28, Alligator mississippiensis. Musculus adductor mandibulae externus $(1,8,15,22) ;$ Musculus adductor mandibulae posterior (2,9,16,23), Musculus pterygoideus dorsalis (3,10,17,24), Musculus pterygoideus ventralis $(4,11,18,25)$, Musculus pseudotemporalis $(5,12,19,26)$, Musculus intramandibularis $(6,13,20,17)$, Musculus depressor mandibulae $(7,14,21,28)$. Arrows represent the line of action of each muscle. Red lines represent the moment arm of each muscle. Not to scale. 


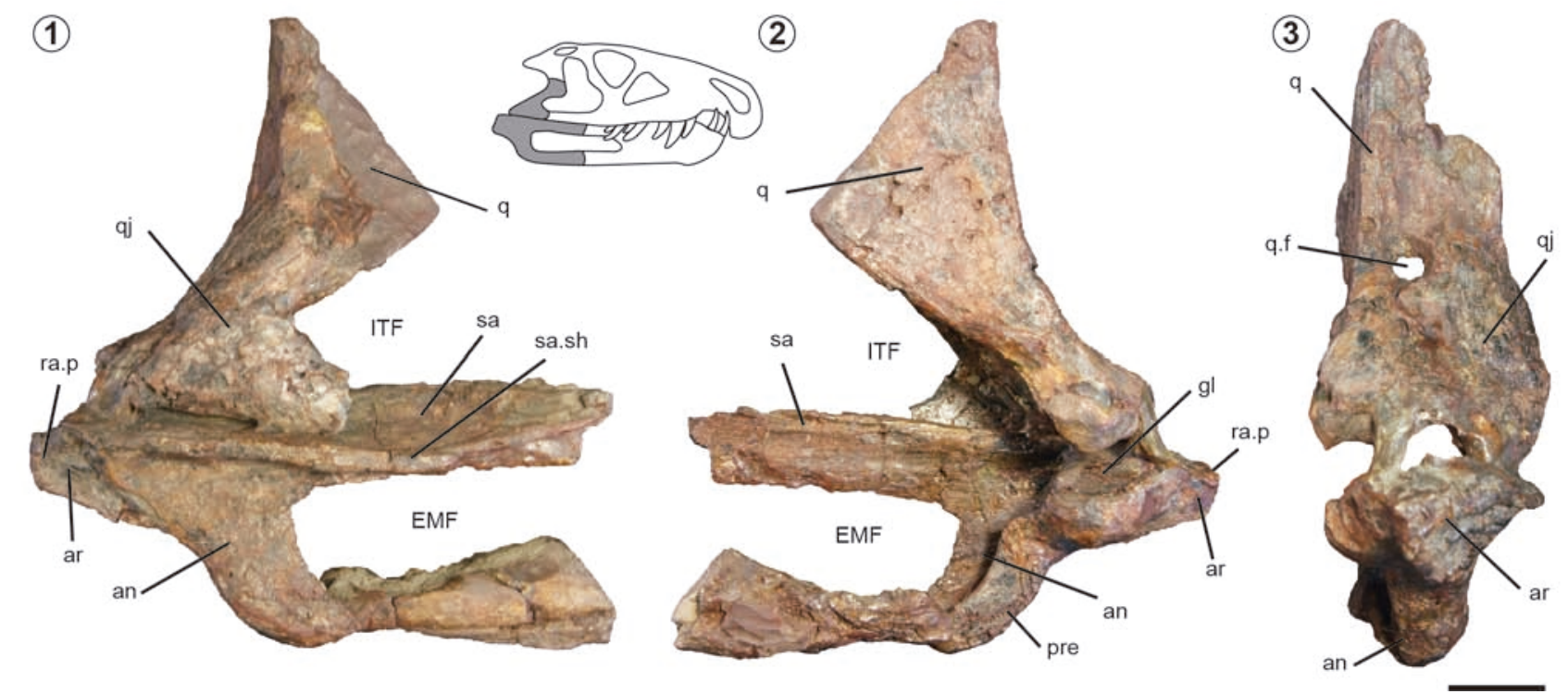



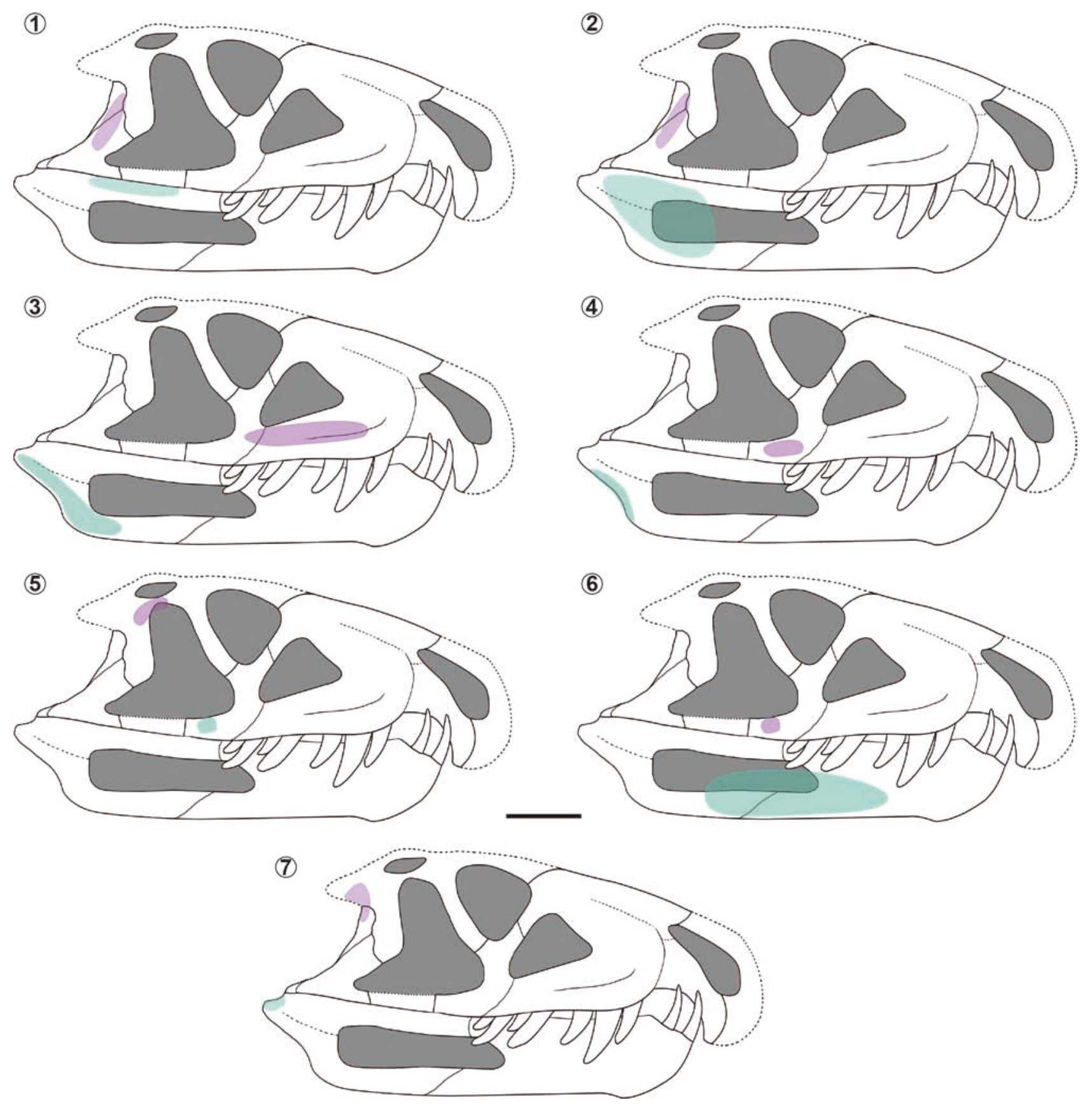

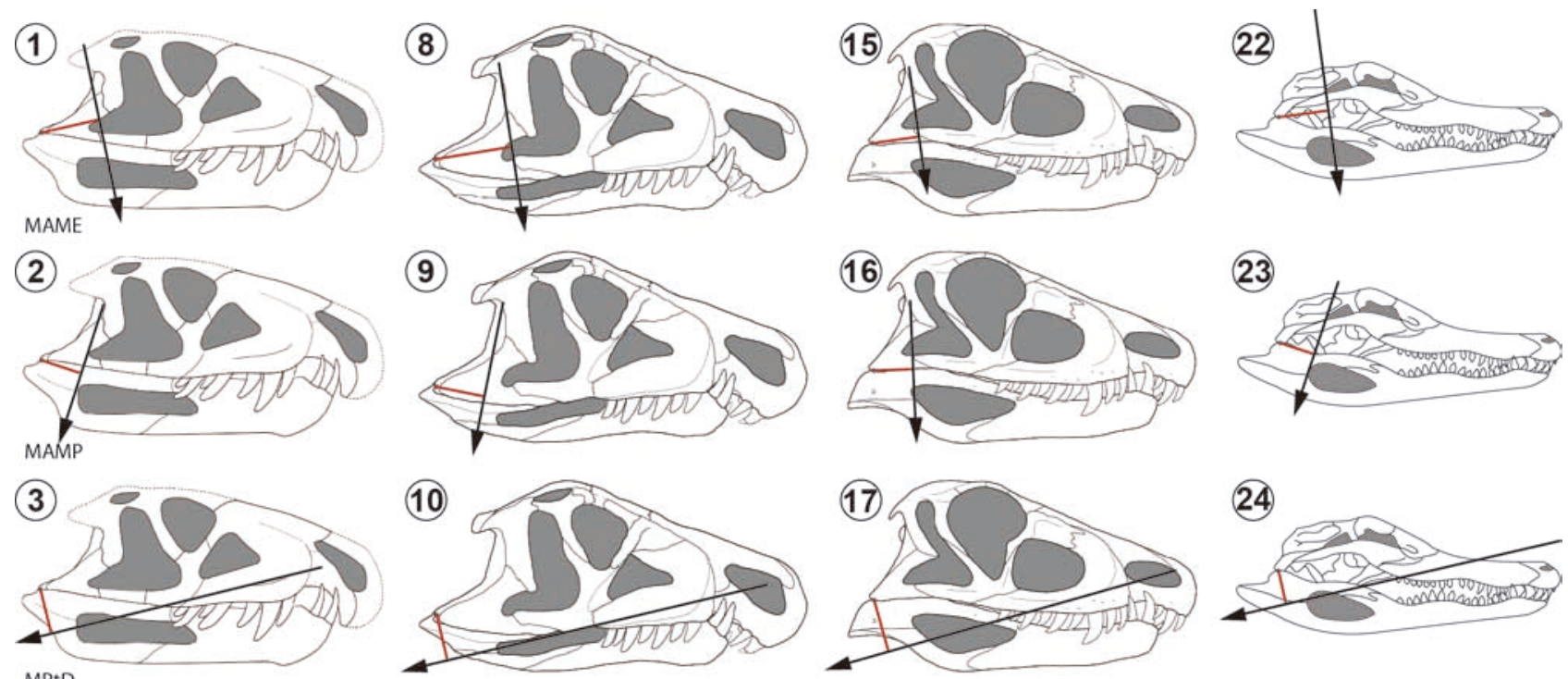

(24)
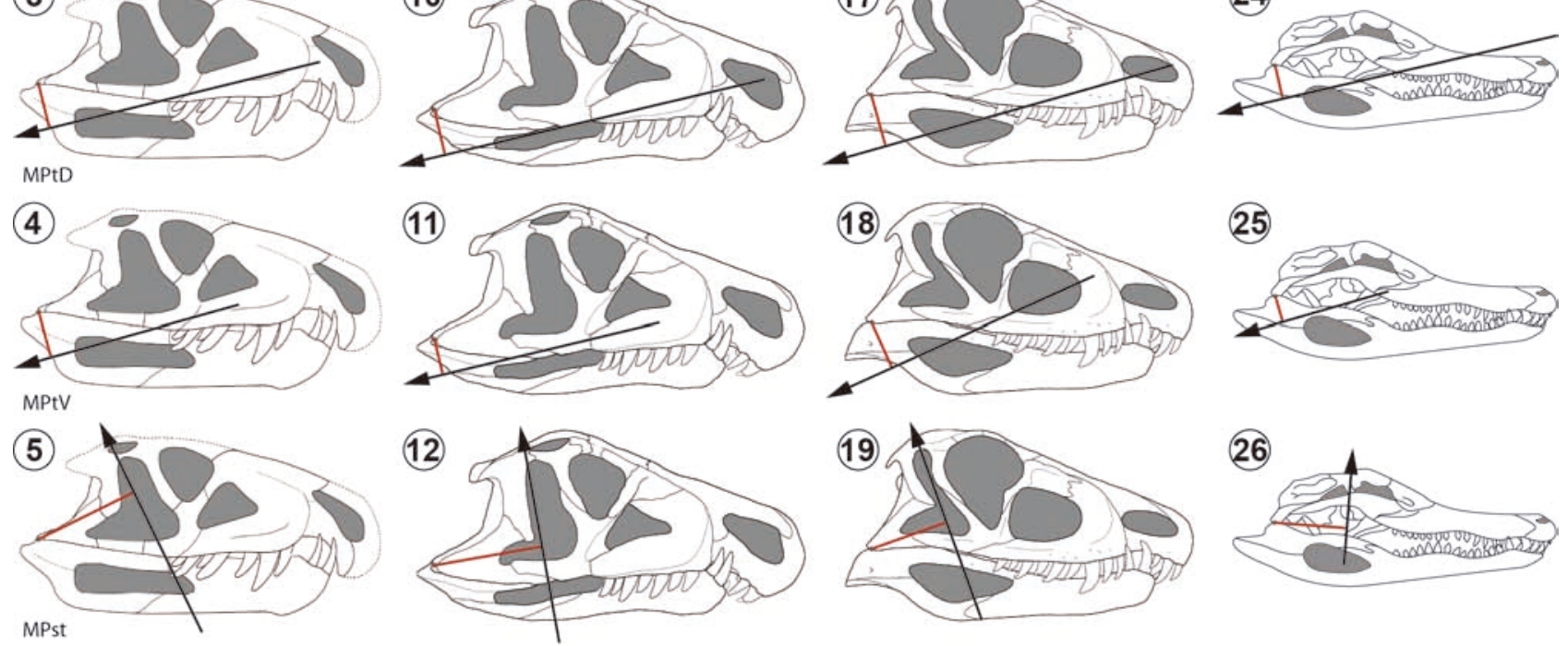

(25)
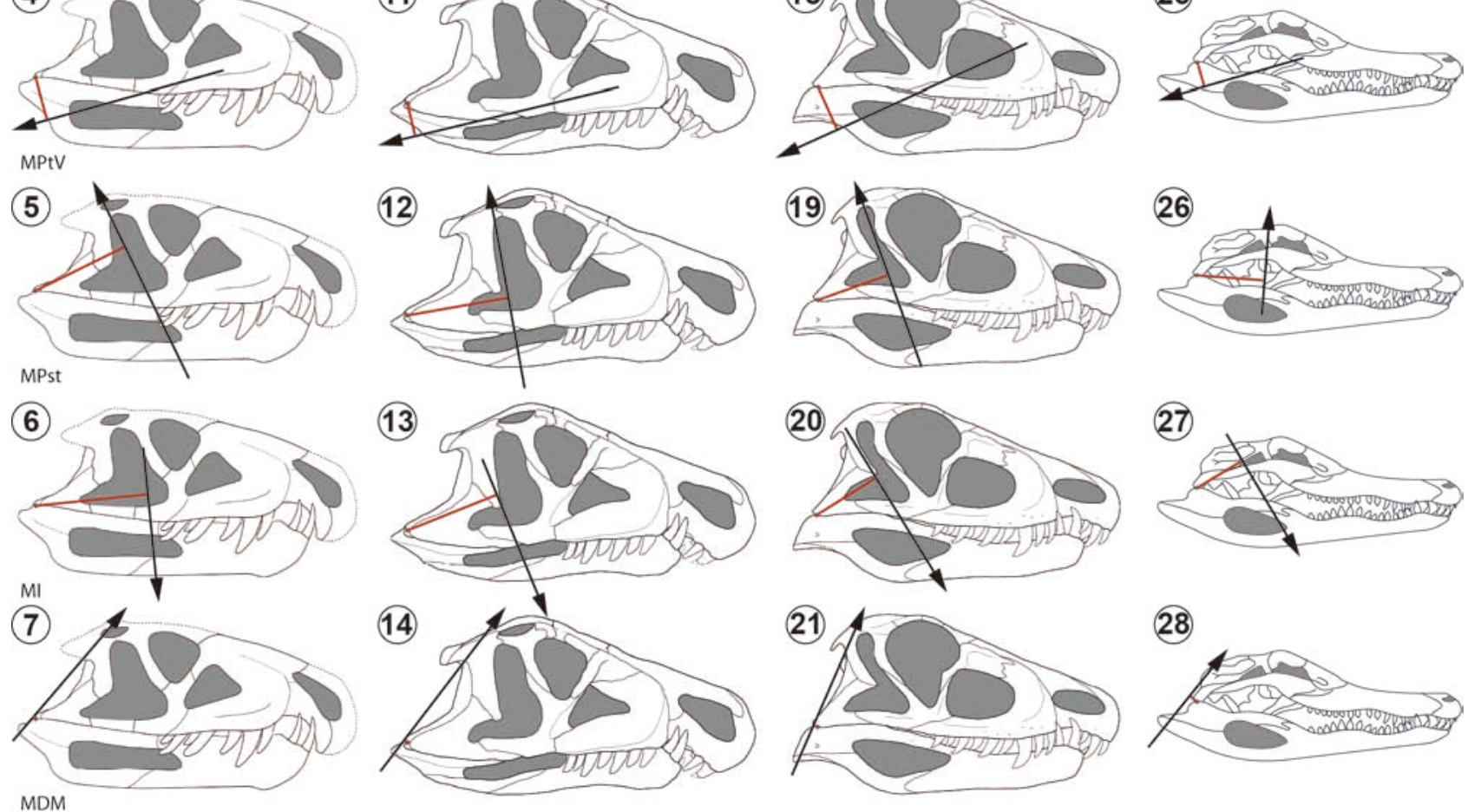

(27)

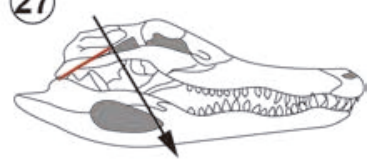

(28)

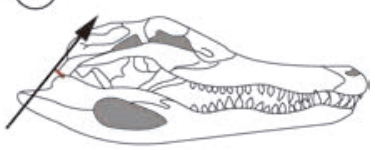




\begin{tabular}{lllllllll}
\hline \hline TABLE 1. Moment arm of the adductor and depressor muscles & & & \\
\hline Taxon & MAME & MAMP & MPtD & MPtV & MPst & MI & AM & MDM \\
\hline \multirow{2}{*}{ Venaticosuchus } & 19.5 & 13.0 & 14.0 & 13.0 & 35.0 & 39.0 & 133.5 & 1.5 \\
& $(14.6 \%)$ & $(9.7 \%)$ & $(10.5 \%)$ & $(9.7 \%)$ & $(26.2 \%)$ & $(29.2 \%)$ & & \\
Riojasuchus & 24,0 & 15,0 & 13,0 & 10,0 & 36,0 & 32,0 & 130,0 & 3.0 \\
Ornithosuchus & $(18.5 \%)$ & $(11.5 \%)$ & $(10 \%)$ & $(7.7 \%)$ & $(27.7 \%)$ & $(24.6 \%)$ & & \\
\multicolumn{10}{c}{ Alligator } & 14,0 & 12,0 & 17,5 & 15,5 & 27,0 & 26,0 & 112.0 & 2.0 \\
& $(12.5 \%)$ & $(10.7 \%)$ & $(15.6 \%)$ & $(13.8 \%)$ & $(24.1 \%)$ & $(23.2 \%)$ & & \\
\hline Musculus adductor mandibulae externus (MAME), Musculus adductor mandibulae posterior \\
(MAMP), Musculus pterygoideus dorsalis (MPtD), Musculus pterygoideus ventralis (MPtV), \\
Musculus pseudotemporalis (MPst), Musculus intramandibularis (MI), total adductor muscles \\
(AM), and Musculus depressor mandibulae (MDM) of ornithosuchids and Alligator. Contribution to \\
the total adductor moment arm in parenthesis. \\
\hline \hline
\end{tabular}




\begin{tabular}{|c|c|c|c|c|c|c|}
\hline Taxon & MAME+MAMP & MPtD+MPtV & MPst & $\mathrm{MI}$ & AM & MDM \\
\hline Venaticosuchus & $\begin{array}{l}32,5 \\
(24,3 \%)\end{array}$ & $\begin{array}{l}27 \\
(20,2 \%)\end{array}$ & $\begin{array}{l}35 \\
(26,2 \%)\end{array}$ & $\begin{array}{l}39 \\
(29,2 \%)\end{array}$ & 133,5 & 1,5 \\
\hline Riojasuchus & $\begin{array}{l}39 \\
(30 \%)\end{array}$ & $\begin{array}{l}23 \\
(17,7 \%)\end{array}$ & $\begin{array}{l}36 \\
(27,7 \%)\end{array}$ & $\begin{array}{l}32 \\
(26 \%)\end{array}$ & 130,0 & 3,0 \\
\hline Ornithosuchus & $26(23,2 \%)$ & $33(29,5 \%)$ & $\begin{array}{l}27 \\
(24,1 \%)\end{array}$ & $\begin{array}{l}26 \\
(23,2 \%)\end{array}$ & 112,0 & 2,0 \\
\hline Alligator & $\begin{array}{l}27,0 \\
(27 \%)\end{array}$ & $\begin{array}{l}20,0 \\
(20 \%)\end{array}$ & $\begin{array}{l}34,0 \\
(34 \%)\end{array}$ & $\begin{array}{l}19,0 \\
(19 \%)\end{array}$ & 100,0 & 3,5 \\
\hline Neoaetosauroide & $\begin{array}{l}17 \\
(20,7 \%)\end{array}$ & $\begin{array}{l}9 \\
(11 \%)\end{array}$ & $\begin{array}{l}28 \\
(34,1 \%)\end{array}$ & $\begin{array}{l}28 \\
(34,1 \%)\end{array}$ & 82,0 & 8,5 \\
\hline Stagonolepis & $\begin{array}{l}17 \\
(21,8 \%)\end{array}$ & $\begin{array}{l}10 \\
(12,8 \%)\end{array}$ & $\begin{array}{l}25 \\
(32,1 \%)\end{array}$ & $\begin{array}{l}26 \\
(33,3 \%)\end{array}$ & 78,0 & 7,0 \\
\hline Desmatosuchus & $\begin{array}{l}19 \\
(23,5 \%)\end{array}$ & $\begin{array}{l}13 \\
(16 \%)\end{array}$ & $\begin{array}{l}24 \\
(29,6 \%)\end{array}$ & $\begin{array}{l}25 \\
(30,9 \%)\end{array}$ & 81,0 & 9,0 \\
\hline $\begin{array}{l}\text { Values of MAME } \\
\text { results of Desojo } \\
\text { parenthesis. }\end{array}$ & $\begin{array}{l}\text { MAMP, MPtD a } \\
\text { Vizcaíno (2009) }\end{array}$ & $\begin{array}{l}\text { MPtV were a } \\
\text { ontribution tc }\end{array}$ & $\begin{array}{l}\text { Ided to } b \\
\text { the total }\end{array}$ & $\begin{array}{l}\text { le to co } \\
\text { uctor } m\end{array}$ & $\begin{array}{l}\text { are wit } \\
\text { ent arr }\end{array}$ & \\
\hline
\end{tabular}


TABLE 3. Moment arms of bite calculated at the posterior (Mb1) and anterior (Mb2) maxillary teeth, and the posterior premaxillary teeth (Mb3).

\begin{tabular}{|c|c|c|c|c|c|c|c|c|}
\hline Taxon & Mb1 & $\mathrm{Mb2}$ & Mb3 & R1 & $\mathrm{R} 2$ & R3 & $x$ & AM \\
\hline Venaticosuchus & 44 & 79 & N/A & 3,03 & 1,69 & $\mathrm{~N} / \mathrm{A}$ & 2,36 & 133,5 \\
\hline Riojasuchus & 54 & 82,5 & 92 & 2,41 & 1,58 & 1,41 & 1,8 & 130,0 \\
\hline Ornithosuchus & 40,5 & 81 & 95 & 2,77 & 1,38 & 1,18 & 1,78 & 112,0 \\
\hline \multicolumn{9}{|l|}{ Alligator } \\
\hline combined & 40 & 81 & 90,5 & 2,11 & 1,04 & 0,94 & 1,36 & 84.5 \\
\hline Neoaetosauroides & 46 & 76 & 89,5 & 1,78 & 1,08 & 0,92 & 1,26 & 82,0 \\
\hline Stagonolepis & 47 & 76 & 89 & 1,66 & 1,03 & 0,88 & 1,19 & 78,0 \\
\hline Desmatosuchus & 39 & 71 & N/A & 2,08 & 1,14 & $\mathrm{~N} / \mathrm{A}$ & 1,61 & 81,0 \\
\hline
\end{tabular}

